\title{
Study in the Effect of Yavavati in the Management of Dyslipidemia
}

\author{
Research Article
}

\section{Tejas Laxman Kakade ${ }^{*}$, Sadhana Misar Wajpeyi²}

1. Assistant Professor, Department of Kayachikitsa, MGAC \& RC, Salod, Wardha, Maharashtra, India 2. Professor, Department of Swasthavrutta, MGAC \& RC, Salod, Wardha, Maharashtra, India

\begin{abstract}
Dyslipidemia is considered as metabolic disorders related to lipoprotein metabolism, manifested as rise in plasma levels of total Cholesterol, Triglyceride (TGs), or both, or a decrease in high density lipoprotein level or all three together that contributes to the formation of atherosclerosis. It can be included under santarpanjanyavyadhi. Various conditions like Shonitabhishyandana, Rasagata SnehaVriddhi (raised plasma lipid levels), Rasaraktagata Snehavriddhi (raised plasma and blood lipid levels), Medovriddhi (elevation of generalized fat), Medoroga (obesity), Aam Medodhatu (abnormal form of adipose tissue) can be correlated with Dyslipidemia due to resemblance of their etiopathogenesis and clinical features. Total 30 patients of dyslipidemia fulfilling the diagnostic criteria were selected and treated with Yavavati $1.5 \mathrm{gm}$ twice a day before meal with lukewarm water for 30 days. In this study it was observed that incidence of Dyslipidemia was more in advanced ages,female gender, middle socioeconomic group individuals having vatapittajaprakruti, madhyamagni and madhyamaakruti. In present study, sedentary lifestyle, day sleep, association of other diseases like hypertension, DM, hypothyroidism and hemiplegia are the main causative factors for Dyslipidemia. Yavavati showed significant improvement in BMI, total cholesterol, S.Triglicerides, S.VLDL and HDL level. This improvement may be due to its ruksha, lekhana, kaphamedahar, agnivadhaka and apatarpana properties of Yavavati. Hence from this study it can be concluded that, Yavavati is effective and can be safely used in the management of Dyslipidemia.
\end{abstract}

Key Words: Dhamnipratichaya, Dyslipidemia, Medorog, Yava.

\section{Introduction}

The Human life is rapidly changing in its food, standard of living and environment. Because of changes in food pattern and sedentary lifestyle a majority of population is suffering from metabolic disorders.

Change in the normal metabolic processes due to abnormal chemical reactions in the body leads to metabolic disorders. Dyslipidemia is considered as metabolic disorders related to lipoprotein metabolism, manifested as rise in plasma levels of total Cholesterol, Triglyceride (TGs), or both, or a decrease in high density lipoprotein level or all three together that contributes to the formation of atherosclerosis in any stage of life. $(1,2)$

There is no any description of Dyslipidemia found in Ayurvedic text. So it cannot be compare with particular disease in Ayurveda. It can be included under santarpanjanyavyadhi. Various conditionslike Shonitabhishyandana, Rasagata SnehaVriddhi (raised plasma lipid levels), RasaRaktagata SnehaVriddhi

\section{* Corresponding Author:}

\section{Tejas Laxman Kakade}

Assistant Professor, Department of Kayachikitsa, MGAC \& RC, Salod, Wardha, 442001, Maharashtra, India

Email Id: tejaskkd22@gmail.com (raised plasma and blood lipid levels), Medovriddhi (elevation of generalized fat), Medoroga (obesity), Aam Medodhatu (abnormal form of adipose tissue)(3) can be correlated with Dyslipidemia due to resemblance of their etiopathogenesis and clinical features.

Bad food habits, sedentary lifestyle (4), presence of Dyslipidemia in family, intake of alcohol, cigarette smoking and stress are the main etiological factors of Dyslipidemia. According to Ayurveda guru, madhur, sheet, snigdha, kaphamedavardhaka ahar, avyayam, diwaswapa, achinta and bijadosha are the main causative factors for medoroga(5). All these hetus lead to aggravation of kapha and meda which causes strotorodha. Due to stotorodha there is obstruction to the normal movement of vayu. This obstructed vayu comes into the koshtha and causes jatharagni sandhukshana (increase capacity of digestion) which causes early digestion of ingested food leading to voracious hunger and craving for large quantity of food. According to Dalhan agnimandya and ama production are responsible for this condition.

All metabolic activities in the body are mainly depends on proper functioning of Agni(6). Agnimandya causes improper digestion of food and produces Ama. In Ayurveda Ama is believed to be the key factor in the pathogenesis of metabolic disorders. This ama causes obstruction in strotas (channels of metabolic processes) which leads to disease formation. Due to impairment in 
the fat metabolism excess fat get accumulated in blood and adipose tissue.

Due to Medodhatwagnimandya, formation of abnormal poshakamedodathu in large quantity takes place. This abnormally formed poshakamedodathu in large quantity get accumulated in rasadhatu. Accumulation of poshakamedodhatu results into formation of disorder called as Dhamanipratichaya. Dhamanipratichaya is one of the 20 nanatmajavyadhis of KaphaDosha.(7)Samprapti of medoroga starts with accumulation of aggravated kapha and medas in the various strotasa causing strotorodha. This excess of kapha and medas in the blood is referred as shonitabhishyandana in which there is excessive accumulation of kaphaand medas within the rasadhatu (plasma)and raktadhatu (blood vessels) (8) which forms the upalepa within the walls of the dhamani and adheres to it(9). In Ayurveda to remove this upalepa of kaphamedaapatarpana, karshana and kaphamedanashana chikitsa is given by Acharya Charak. Yava is mentioned in Bhavprakash(10) for the management of medoroga which helps in sampraptivighatana.

\section{Aim and objectives}

Aim

Study in the Effect of Yavavati in the management of Dyslipidemia.

\section{Objectives}

1.To study the effect of Yavavati on Body Mass Index (BMI).

2.To study the effect of Yavavati on Total cholesterol.

3.To study the effect of Yavavati on Triglyceride.

4.To study the effects of Yavavati on HDL.

\section{Material and methods}

\section{Material -}

Patients reported to OPD and IPD of Kayachikitsa Department, and also from the peripheral camps were enrolled for this study.

\section{Method}

Study was started after obtaining approval from Institutional ethics committee (Ref. number. DMIMS (DU)/IEC/2017-18/6391) on 30/3/2017.

\begin{tabular}{|c|c|}
\hline Study Design & Single arm. \\
\hline Study Type & It was an interventional study. \\
\hline Place of Study & $\begin{array}{l}\text { OPD and IPD of Kayachikitsa, } \\
\text { MGACH \& RC Salod(H) Wardha }\end{array}$ \\
\hline Sample Size & 30 patients \\
\hline Grouping & Single \\
\hline
\end{tabular}

\section{Inclusion Criteria}

- Subjects of Dyslipidemia having age between 20-60 years irrespective of sex.

- Subjects fulfilling the following diagnostic criteria of Dyslipidemia.

\section{Diagnostic Criteria(11)}

\begin{tabular}{|c|c|c|}
\hline \multicolumn{2}{|c|}{ Serum Total cholesterol } & $200-240 \mathrm{mg} / \mathrm{dl}$ \\
\hline \multicolumn{2}{|c|}{ Serum Triglycerides } & $150-200 \mathrm{mg} / \mathrm{dl}$ \\
\hline Serum HDL- & Men & $35-55 \mathrm{mg} / \mathrm{dl}$ \\
\hline Cholesterol & Women & $45-65 \mathrm{mg} / \mathrm{dl}$ \\
\hline
\end{tabular}

\section{Exclusion Criteria}

- Pre-diagnosed cases of major illness like cardiovascular disorder, renal disorders, and polycystic ovary syndrome.

- Hyperlipidemia due to consumption of drugs such as glucocorticoids.

- During pregnancy and lactation period in women.

\section{Composition of Material}

Table No- 1: Showing the ingredient of Yavavati (12)

\begin{tabular}{|r|l|l|l|} 
Sr.no & Ingredients & Botanical name & Part used \\
1 & Yava & $\begin{array}{l}\text { Hordeum } \\
\text { vulgare Linn. }\end{array}$ & Grain \\
\hline
\end{tabular}

\section{Preparation of Material (Yavavati): (13)}

\begin{tabular}{|c|c|}
\hline $\begin{aligned} & \\
& \text { Fine powder of } 50 \% \\
& \downarrow \\
& \downarrow \\
& \downarrow \\
& \downarrow \\
& \downarrow \\
& \downarrow\end{aligned}$ & $\begin{array}{c}\text { Coarse powder of 50\% } \\
\downarrow \\
\text { Coarse powder divided in } 3 \\
\text { equal parts } \\
\downarrow \\
\text { Kwath was prepared from } \\
1 / 3 \text { rd part of Coarse powder } \\
\downarrow \\
\text { Bhavana was given to Fine } \\
\text { powder } \\
\downarrow \\
\text { Total } 3 \text { bhavana given } \\
\text { (Using } 1 / 3 \text { rd part of Coarse } \\
\text { powder each time) } \\
\downarrow \\
\text { Granules prepared } \\
\downarrow \\
\text { Vati of } 500 \text { mg was prepared } \\
\text { from granules }\end{array}$ \\
\hline
\end{tabular}

\section{Dosage}

$1.5 \mathrm{gm}$ potentiated with the YavaKwath (churnakriya) twice a day (6-7 am) and (8-9 pm) before food intake with koshnajal.

\section{Study Duration}

30 Days 


\section{Follow Up Period}

Follow up was done on $15^{\text {th }}$ and $30^{\text {th }}$ day.

\section{Investigation}

Lipid Profile:

1) Total cholesterol.

2) Triglycerides.

3) HDL (High density lipoprotein)
Objective Parameters

-BMI (Body Mass Index)

-Lipid profile:-

2) Triglycerides.

3) HDL (High density lipoprotein)

\section{Observations and results}

Statistical analysis was done by using descriptive and inferential statistics using Student's paired t test and software used in the analysis was SPSS 22.0 version and $\mathrm{p}<0.05$ is considered as level of significance.

Table No- 2: Comparison of BMI at day $0,15^{\text {th }}$ and $30^{\text {th }}$; Student's paired $t$ test

\begin{tabular}{|l|c|c|c|c|c|c|c|c|}
\hline & Mean & $\mathrm{N}$ & Standard Deviation & Standard Error Mean & Mean Difference & t-value & $\mathrm{p}$ value \\
\hline Baseline & 25.47 & 30 & 3.63 & 0.66 & - & - & \\
\hline $15^{\text {th }}$ day & 25.36 & 30 & 3.58 & 0.65 & $0.11 \pm 0.32$ & 1.86 & $\begin{array}{c}0.072, \\
\text { Not Significant }\end{array}$ \\
\hline 30th day & 25.28 & 30 & 3.56 & 0.65 & $0.18 \pm 0.39$ & 2.06 & $\begin{array}{c}0.048, \\
\text { Significant }\end{array}$ \\
\hline
\end{tabular}

Mean of BMI was 25.47 before treatment which decreased to 25.36 on $15^{\text {th }}$ day and then reduced to 25.28 on $30^{\text {th }}$ day with significant t- value 2.06 and $p$ - value 0.048

Table No- 3: Comparison of HDL before and after treatment; Student's paired $t$ test

\begin{tabular}{|c|c|c|c|c|c|c|}
\hline & Mean & $\mathrm{N}$ & Standard Deviation & Standard Error Mean & Mean Difference & $\mathrm{t}$-value \\
\hline Before $\mathrm{t} / \mathrm{t}$ & 38.60 & 30 & 8.36 & 1.52 & & 5.25 \\
$\mathrm{p}=0.0001$, & $5.33 \pm 5.56$ & Significant \\
\hline After $\mathrm{t} / \mathrm{t}$ & 43.93 & 30 & 6.67 & 1.21 & &
\end{tabular}

This study showed that Mean of HDL was 38.60 before treatment that increased to 43.93 after treatment with significant $5.25 \mathrm{t}-$ value and $0.0001 \mathrm{p}$-values.

Table No- 4: Comparison of Total Cholesterol before and after treatment; Student's paired $t$ test

\begin{tabular}{|c|c|c|c|c|c|c|}
\hline & Mean & N & Standard Deviation & Standard Error Mean & Mean Difference & $\mathrm{t}$-value \\
\hline Before $\mathrm{t} / \mathrm{t}$ & 220.53 & 30 & 14.53 & 2.65 & & 10.64 \\
\hline After $\mathrm{t} / \mathrm{t}$ & 204.10 & 30 & 14.34 & 2.61 & $16.43 \pm 8.48$ & $\begin{array}{c}\mathrm{p}=0.0001, \\
\text { Significant }\end{array}$ \\
\hline
\end{tabular}

In present study, mean of total cholesterol was 220.53 before treatment that decreased to 204.10 after treatment with significant $\mathrm{t}$ - value 10.64 and $\mathrm{p}$ - value 0.0001 .

Table No- 5: Comparison of LDL before and after treatment; Student's paired $t$ test

\begin{tabular}{|c|c|c|c|c|c|c|}
\hline & Mean & $\mathrm{N}$ & Standard Deviation & Standard Error Mean & Mean Difference & $\mathrm{t}$-value \\
\hline Before $\mathrm{t} / \mathrm{t}$ & 151.60 & 30 & 16.90 & 3.08 & & 9.92 \\
$\mathrm{p}=0.0001$ & \\
\hline After $\mathrm{t} / \mathrm{t}$ & 134.00 & 30 & 16.41 & 2.99 & $18.16 \pm 10.02$ & $\begin{array}{c}\mathrm{p}=0.001 \\
\text { Significant }\end{array}$ \\
\hline
\end{tabular}

In this study mean of LDL was 151.60 before treatment that decreased significantly to 134.00 after treatment with t-value 9.92 and $p$ - value 0.0001

Table No- 6: Comparison of Triglyceride before and after treatment; Student's paired $t$ test

\begin{tabular}{|c|c|c|c|c|c|c|}
\hline & Mean & $\mathrm{N}$ & Standard Deviation & Standard Error Mean & Mean Difference & $\mathrm{t}$-value \\
\hline Before $\mathrm{t} / \mathrm{t}$ & 148.96 & 30 & 36.78 & 6.71 & & 6.80 \\
\hline After $\mathrm{t} / \mathrm{t}$ & 131.13 & 30 & 30.60 & 5.58 & $17.83 \pm 14.35$ & $\begin{array}{c}\mathrm{p}=0.0001, \\
\text { Significant }\end{array}$ \\
\hline
\end{tabular}

In this study it was observed that mean Triglyceride before treatment was 148.96 which reduced to 131.13 after treatment with significant $6.80 \mathrm{t}$ - value and $0.0001 \mathrm{p}$-value 
Tejas Kakade et.al., Study in the Effect of Yavavati in the Management of Dyslipidemia

Table No- 7: Comparison of VLDL before and after treatment; Student's paired $t$ test

\begin{tabular}{c|c|c|c|c|c|c|} 
& Mean & $\mathrm{N}$ & Standard Deviation & Standard Error Mean & Mean Difference & $\mathrm{t}$-value \\
\hline Before $\mathrm{t} / \mathrm{t}$ & 29.50 & 30 & 7.35 & 1.34 & & 6.92 \\
$\mathrm{After} \mathrm{t} / \mathrm{t}$ & 26.16 & 30 & 6.10 & 1.11 & $3.70 \pm 3.92$ & $\mathrm{p}=0.0001$, \\
Significant
\end{tabular}

In this study, mean of VLDL was 29.50 before treatment that decreased significantly to 26.16 with $\mathrm{t}$ - value 6.92 and $\mathrm{p}$ - value 0.0001 after treatment.

\section{Discussion}

The research study entitled "Study in the Effect of Yavavati in the management of Dyslipidemia" was carried out to assess the efficacy of Yavavati in the management of Dyslipidemia. Total 30 patients having diagnostic criteria were enrolled from OPD and IPD of Kayachikitsa Department for the study.

All 30 patients were treated with Yavavati(1.5 gm.) two times a day with koshnajal before intake of food for the period of 30 days. Data of patient was collected by filling in specially designed case proforma. BMI was assessed on $0,15^{\text {th }}$, and $30^{\text {th }}$ day and the lipid profile was done on 0 and $30^{\text {th }}$ day. Statistical analysis was carried out to attain ultimate result as well as conclusion.

- In this research work, maximum patients $(43.33 \%)$ belonged to age group of 51- 60 years. Advanced age is one of the risk factors for Dyslipidemia and also diabetes, hypertention, obesity are associated with Dyslipidemia. The prevalence of these diseases also increases with age. In females as the age advances there are more chances of hormonal imbalance due to menopausal stage which increases the prevalence of Dyslipidemia.

- Present study showed that more patients were $(53.33 \%)$ female.

- In present study number of housewives (40\%), were more. The reason for increased prevalence in housewives may be due higher prevalence of dyslipidemia in female and may be due to sedentary lifestyle, lack of exercise, improper diet, stress and hormonal imbalance in female. $(14,15)$

- In present study, $96.67 \%$ patients were married. Incidence of Dyslipidemia was more in married. This may be due to the patients taken for study were in between the age group of 20- 60 years and maximum numbers of patients were in the advanced age i: e 51-60, hence prevalence is more in married people. It may be due to increased responsibilities and stress in married people, which is one of the causative factors of Dyslipidemia.

- In present study (66.67\%) patients were from middle socio-economic class. In middle socio-economic class more incidence of Dyslipidemia may be due to their unawareness regarding dietary habits, importance of exercise and regular health checkup.
Dyslipidemia has no any specific symptoms hence in most of the patients it remains undiagnosed.

- Present study showed maximum (60\%) patients from rural habitat.

- In this study, majority of the patients $56.67 \%$ had no any history of other diseases like hypertension, diabetes mellitus, hypothyroidism and hemiplegia, only $43.33 \%$ patients had history of association of one or more above said disorders. These disorders contribute to secondary causes of Dyslipidemia hence association of these diseases are observed with Dyslipidemia. (16)

- In this study maximum number of patients $93.33 \%$ had no family history of Dyslipidemia. It indicates that the Dyslipidemia may be of secondary type which may be caused due to unhealthy dietary habits, alcohol consumption, sedentary lifestyle, diabetes mellitus, hypothyroidism, endocrine disorders and use of drug such as thiazide diuretics, beta blockers and estrogens. (17)

- In present study majority of $(63.33 \%)$ patients were having mixed diet. Acharya Charak has mentioned mamsasevan as one of the hetu of medoroga(18)but the diet can be varied by the region, so exact conclusion cannot be drawn in regards with diet.

- In this study, according to distribution of habit it was observed that $25(83.33 \%)$ patients had addiction of tea, $10(33.33 \%)$ patients had addiction of tobacco, $4(13.33 \%)$ patients had addiction of alcohol and $4(13.33 \%)$ patients had no any type of addiction. From these variations it was difficult to draw any conclusion but alcohol consumption and smoking both are contributing factors of Dyslipidemia. (19)

- In present study, it was found that more number of subjects $(96.67 \%)$ had adequate sleep. Sleep is one of the significant factors of metabolic disorders but we did not get any significant finding related to sleep duration. (20)

- In this study most of the patients (60\%) were used to have day sleep. Diwaswap is one of the causes of kaphamedavruddhi described by various Acharyas. (21)

- This study showed that $56.67 \%$ patients were having sedentary type of work. Sedentary lifestyle is major contributing factor for Dyslipidemia. (22).

- Present study showed that maximum number of patients used to have physical as well as mental type of work pattern. Stress and sedentary lifestyle are associated with Dyslipidemia. (23) 
- In this study, maximum patients $70 \%$ were having madhyamakriti. Sthulaakriti (obesity) is major risk factor of Dyslipidemia (24)

- In this study majority of patients had vata-pittaj and vata-kaphajprakriti. Medoroga is prevalent in kapha dominant prakriti. Regarding prakriti, this study showed vata predominance with pitta and kapha.

- In this study Maximum patient $66.67 \%$ had madhyamagni, Mandagni is major causative factor for all metabolic disorders, but we did not get this causative factor in present study. (25)

- In present study $90 \%$ patients had samyak Malapravrutti(bowel habit). In this study we found no any correlation of malapravrutti and Dyslipidemia.

- Mean of BMI, before treatment was 25.47 which decreased to 25.36 on $15^{\text {th }}$ day (t- value 1.86 , $\mathrm{p}=0.072$ ) and then significantly reduced to 25.28 on $30^{\text {th }}$ day ( $\mathrm{t}$ - value 2.06 and $\mathrm{p}$ - value 0.048 ). The reduction in BMI may be due to kaphamedahar, lekhana and apatarpan properties of Yava.

- Mean of HDL was 38.60 before treatment that increased to 43.93 after treatment with significant t5.25 values and p-value 0.0001 . Total cholesterol before treatment was 220.53 which significantly decreased to 204.10 after treatment with t- value 10.64 and p- value 0.0001. Mean of LDL was 151.60 before treatment which significantly decreased to 134.00 after treatment with significant t-value 9.92 and p- value 0.0001.Mean Triglyceride before treatment was 148.96 which reduced to 131.13 after treatment with significant $\mathrm{t}$ - value 6.80 and $\mathrm{p}$ values0.0001. Mean of VLDL was 29.50 before treatment which significantly reduced to 26.16 after treatment with significant $\mathrm{t}$ - value 6.92 and $\mathrm{p}$ - value 0.0001 .This significant improvement in serum lipid levels may be due to ruksha, kaphamedahar, agnivardhaka and lekhana properties of yava(26).

\section{Probable Mode of Action of Yavavati}

Yavavati consists of Yava and it is prepared by giving bhavana of yavakwatha to yavachurna. Samprapti of Medoroga mainly consists of medadhatuagnimandya, aggravation of kaphameda and strotorodha. (27)

Yava has Madhura, Kashayarasa; Guru, Ruksha, guna; Sheetavirya and Katuvipaka. It possesses kaphapittashamak, lekhana,agnivardhak and medohar properties due to which it is useful in medoroga. (28)

Agnivardhak property of yava helps in correcting the agnimandya which is the main cause of medoroga. Kaphamedahar property of yava helps in reducing aggravated kapha and meda. Lekhana property of yava leads to reduce excessive meda and thereby opens the obstructed channels. Lekhana property of yava enables scrapping action and thus helps in removing the upalepa of meda in the walls of dhamani.
All these properties of yava made possible to reverse the pathological mechanism thus correcting the root cause of disease. Yava is included in shukadhanyavarga having high nutritive value which helps in the nourishment of all dhatus. (29)

In Modern literature it is described that (yava) Barley has high fiber content, beta glucan. Various research studies conducted on barley proved that consumption of barley containing food significantly improves the several CVD risk factors.(30) Beta glucans content of Barley are useful in lowering the serum lipids. Beta glucans has property of gel forming, so beta glucan helps in increasing viscosity of intestinal chyme and the micelle formation gets disturb due to increased viscosity. Thus it inhibits cholesterol absorption and increases bile acid excretion by inhibiting bile acid re-absorption. Various research studies also showed that barley has antihypercholesterolemic activity. (31)

In this study significant reduction in BMI and significant improvement in serum lipid levels may be due all above mentioned properties and action of Yava. Hence it can be effectively used in the management of Dyslipidemia.

\section{Conclusion}

The term Dyslipidemia is not described in classics of Ayurveda, but can compared with certain conditions like medoroga, Rasaraktagata snehavruddhi, shonitabhishyandana, dhamanipratichaya on the basis of resemblance of etiopathogenesis and symptoms.

In this study it was observed that incidence of Dyslipidemia was more in advanced ages, female gender, middle socioeconomic group individuals having vatapittajaprakruti, madhyamagni and madhyamaakruti.

In present study, sedentary lifestyle, day sleep, association of other diseases like hypertension, DM, hypothyroidism and hemiplegia are the main causative factors for Dyslipidemia.

Yavavati showed significant improvement in reduction of $\mathrm{BMI}$, raised total cholesterol, S.Triglicerides, S.VLDL and rise in HDL level may be due to its ruksha, lekhana, kaphamedahar, agnivadhaka and apatarpana properties.

It is rich in soluble fiber beta glucan which inhibits cholesterol absorption from intestine and increases bile acid excretion by inhibiting bile acid reabsorption. Thus helps in lowering the serum lipid levels.

From above results, it can be concluded that, Yavavati is safe, cost effective and easily available hence it can be used in the management of Dyslipidemia.

It is recommended that study should be carried on large sample size with long period. 


\section{References}

1. Kasper. D et.al Harrison's manual of internal medicine 18th edition chapter $356 \mathrm{p}$.

2. Munjal Y P. API textbook of medicine. 9th ed. New Delhi: Jaypee Brothers Medical Publisher; 2012. 1235p.

3. Nandkarni M. et al.: Randomized placebo controlled trial of Mustadi ghanavati in hyperlipidemia. AYU 2010; 31(3):287-93.

4. Sadhana Misar Wajpeyi , Analysis of Etiological Factors of Dyslipidemia -A Case Control Study, International Journal of Ayurvedic Medicine, JanMar., 2020, Vol 11 (1), 92-97.

5. Shukla V, Charak Samhita, Volume-1, Charak Vimansthan, Chapter 5,Verse no 15,Varanasi: Chaukhamba Sanskrit Pratishthan, 2004.

6. Murthy K R S, AshtanghridyamVol 2 Nidansthanch 12 verse 1 Chaukhamba Krishnadas academy Varanasi reprint 2006.

7. Yadavji T. Charak samhita. Sutra Sthana. 20/17.ChaukhambhaOrientalia Publisher: Varanasi. 2009 .115-738.p

8. Yadavji T. Charak samhita. Sutra Sthana. 20/17. ChaukhambhaOrientalia Publisher: Varanasi. 2009 .115-738.p

9. Sharma.S. Ashtangsangraha, Varanasi, chaukambha press, reprint,2008.151,965p

10. Bulusu S Bhavaprakash Ed 2012. Vol I.chapter6 (IX) chaukhambha: Varanasi. 429-430 p.

11. NCEP ATP3 guidelines available at: http:// www.nhlbi.nih.gov/guidelines/ cholesterol/ atglance.pdf Accessed 15th jan, 2016.

12. Bulusu S. Bhavaprakash of bhavmishra. Ed 2012. Vol I.chapter6 (IX) chaukhambha: Varanasi. 429-430 p.

13. Srivastav S, Sharangdhar samhita. Ed reprint 2017. Madhyankhanda, chaukhambha orientalia, Varanasi $117 \mathrm{p}$.

14. Subbarao K et. al, ijrap, Effect Of Trushnadi Loha On Hyperlipidemia- A Clinical Study 4(5) 2013.

15. Kumar. B et al.: a comparative clinical study of tryoshnadiguggulu and lasuna in the management of dyslipidemia. Journal of Ayurveda \& Holistic Medicine Volume-III, Issue-V 2015.

16. Pal. M, API textbook of medicine. 9th ed. New Delhi: Jaypee Brothers Medical Publisher; 2012. $1235 \mathrm{p}$.
17. Pal. M, API textbook of medicine. 9th ed. New Delhi: Jaypee Brothers Medical Publisher; 2012. $1235 \mathrm{p}$.

18. Tripathi R, Charak Samhita sutrasthan, Ch no 27/40 Vol 1, ChaukhambaPratisthan, Varanasi Reprint 2017, 390 p.

19. Kasper D. et al Harrison"s Principles of Internal Medicine, 18th edition(2012), McGraw-Hill publications, Chapter 241; Disorders of Lipoprotein Metabolism, pg.1987

20. Hall M. et al.: Self-Reported Sleep Duration is Associated with the Metabolic Syndrome in Midlife Adults vol 39, No 5, 2008

21. Yadavji T. Charaka samhita. Sutra Sthana. 21/4. Chaukhambha Orientalia Publisher: Varanasi. 2009

22. Kasper D. et al Harrison"s Principles of Internal Medicine, 18th edition(2012), McGraw-Hill publications, Chapter 241; Disorders of Lipoprotein Metabolism, $1987 \mathrm{p}$.

23. Kasper D. et al Harrison"s Principles of Internal Medicine, 18th edition(2012), McGraw-Hill publications, Chapter 241; Disorders of Lipoprotein Metabolism, $1987 \mathrm{p}$.

24. Kasper D. et al Harrison"s Principles of Internal Medicine, 18th edition(2012), McGraw-Hill publications, Chapter 241; Disorders of Lipoprotein Metabolism, $1987 \mathrm{p}$.

25. Murthy K R S, AshtanghridyamVol 2 Nidansthanch 12 verse 1 Chaukhamba Krishnadas academy Varanasi reprint 2006.

26. Sitaram B. Bhavaprakash of bhavmishra. Ed 2012. Vol I.chapter6 (IX) chaukhambha: Varanasi. 429-430 p.

27. Shukla V. " Vaidyamanorama" Hindi Commentary Charak Samhita, Volume-1, Sutrasthan, Chapter 21, Verse No. 5,6, Varanasi; Chaukhambha Sanskrit Pratishtha, 1198; $3001 \mathrm{p}$.

28. Kushwaha H, Charak Samhita , Sutrasthan, Chaukhamba Orientalia Varanasi reprint ed 2014 $410 \mathrm{p}$.

29. Singh A, Bhavprakash Nighantu, DhanyakVarga, Chaukhambha orientalia Varanasi first ed 2007, 246 $\mathrm{p}$ verse no 27-30.

30. Varadacharyulu. $\mathrm{N}$ et al.: Barley Based Food Provide Consumers with Reliable, Healthy Food Choice. 2017. Vol 3(1).

31. Newman, R.K., et al.: Hypocholesterolemic effect of barley foods on healthy men. Nutrition Reports International,1989; 39(4): 749-760p. 